\title{
Kajian atas Relasi Islam dan Demokrasi
}

\author{
Oleh: Miftahul Huda*
}

Perkembangan demokrasi di Indonesia ada relasinya dengan syari'at Islam. Kalaupun dimasukkkan juga unsur militer, militer pun akan bergantung juga pada gerak Islam. Dengan demikian, konsep-konsep Islam harus menjadi promotor bagi perjuaingan demokrasi. Akan tetapi, peran ini tidak akan efektif selama Islam tidak membuka dialog dengan kekuatan politik lainnya. Karena itu, Islam tetap dituntut menjadi Islam yang demokratis.

Kata kunci: Relasi, Islam, Demokrasi

\section{A. Pendahuluan}

Sikap seseorang dalam hidupnya timbul dan dipengaruhi oleh faham yang dianutnya. Paham determinisme mengilhami sikap hidup nihilis, sebaliknya indeterminisme membuka ruang interfensi terhadap takdir. Dalam hal ini, maka ilmu pengetahuan merupakan bagian dari ikhtiar manusia. Oleh karena itu, pada kontek indetermnisme ini maka pembahasan masalah demokrasi merupakan upaya pencarian yang ingin ditemukan dalam Islam

Pada sekitar tahun 60-an seorang orientalis pernah memprediksikan bahwa Islam akan menjadi salah satu kekuatan politik yang sangat penting di dunia, (Watt, 1968). Pengamat yang lain memberikan sinyalemen adanya 'kebangkitan' Islam sebagai gerakan yang semakin go public, yang semakin inklusif, (Douglas, 1996). Padakenyataannya toh dapat dilihat bahwa Islam begitu marak dalam menentukan identitasnya. Begitu banyak aspek kehidupan yang dicarikan dasarnya dari akar Islam, baik yang sekunder (hadits) maupun yang primer (Qur'an). Ada kesan bahwa di setiap aspek kehidupan ini Islam harus memiliki kekhasannya sendiri.

Bersamaan dengan dinamika itu, dalam percaturan politik dunia, kehancuran ideologi komunis menyisakan demokrasi sebagai satu-satunya peradaban politik yang dewasa ini semakin kuat. Kesulitan untuk menyebut demokrasi sebagai ideal type membuka peluang bagi setiap wilayah di dunia ini untuk mencari sosok demokrasi yang operasional. Demokrasi di negara yang satu, kalau boleh dikatakan demikian, berbeda dari demokrasi di negara yang lain. Singkatnya, setiap kekuatan politik mengupayakan cita-cita demokrasi yang realistis bagi negaranya sendiri.

* Penulis adalah Dosen Fakultas Budaya dan Humaniora yang juga candidat doktor pada IAIN Sunan Ampel Surabaya 
Dalam pengertian ini, Islam sebagai suatu kekuatan politik memiliki peluang besar untuk menggali kaidah-kaidah yang bernuansa demokratis. Di situlah kiranya dapat dilihat hubungan antara Islam dan demokrasi. Tulisan ini dimaksudkan untuk memberikan gambaran secukupnya tentang relasi antara Islam dan demokrasi.

Sebelum membahas relasi tersebut, perlu dicatat bahwa demokrasi dalam tulisan ini tidak mengandaikan polemik yang begitu mendetail. Demokrasi di sini cukup dimengerti sebagai suatu kesetaraan politik, perimbangan kekuasaan. Sedangkan Islam dalam hal ini perlu dilihat sebagai suatu kekuatan politik yang, lebih dari sekedar ideologi, memiliki deep driving force untuk menciptakan suatu iklim demokratis. Untuk melihat relasi antara Islam dan demokrasi, baiklah dilihat dahulu agama idiologi terbuka, Islam sebagai suatu kekuatan politik; lalu, demokrasi suatu kesetaraan politik ( kaidah-kaidah demokrasi, Islam dan demokrasi suatu nisbah, Islam versus demokrasi, demokrasi Islam iah), Islam demokratis suatu antisipasi, praktik Islam demokratis, serta kesimpulan yang dapat ditarik tentang relasi antara Islam dan demokrasi.

\section{B. Islam : Suatu Kekuatan politik}

Memandang Islam sebagai suatu kekuatan politik mengandaikan pengertian bahwa Islam memiliki pemahaman integral akan yang duniawi dan yang ukhrawi, (Madjid, 1995). Secara historis dapat dipahami bahwa Islam menghidupi aspek integral antara yang duniawi dan ukhrawi, antara yang rohani dan jasmani. Di sini pantas dicatat bahwa gerakan Nabi (Muhammad) sendiri pada awalnya tidak memiliki relevansi politis yang jelas. Akan tetapi, pada akhirnya gerakan religius Nabi ini disegani juga oleh pedagang-pedagang besar di Mekah. Gagasan religius Nabi menjawab situasi Mekah secara total sehingga lambat laun gerakan Nabi sungguh-sungguh memiliki relevansi bagi kegiatan politik di tanah Arab itu, (Watt, 1968).

Dari perjuangan Nabi dapatlah dilihat bahwa gerakan religiusnya memang memiliki relevansi politis. Keterbukaan dan penghormatan kepada sesama manusia makhluk Allah, misalnya, baginya cukup menjadi basis penggerak untuk membuat komunitas pluralistik (dengan Piagam Medina). Hal inilah yang memungkinkan munculnya pemahaman bahwa Islam sebagai kekuatan politik tidak terlepas dari Islam sebagai suatu gejala teologis. Apa yang dihayati, dihidupi sebagai bagian kerohanian itu terwujud pula dalam kejasmanian. Dengan kata lain, Islam sebagai gejala teologis pun secara historis terejawantah dalam Islam sebagai gejala ideologis. Itu berarti bahwa Islam memiliki ideologi-ideologi yang mendasari bagaimana ia hidup dalam tatanan sosial politik.

Lebih radikal lagi, dalam arti luas, dari sini juga dapat diterima bahwa agama (Islam ) memiliki kaitan yang istimewa dengan negara. Menarikuntuk diperhatikan 
bahwa relatif banyak literatur membahas soal interpretasi terhadap suatu negara Islam (Islam ic state),( Lewis, 1994). Dalam arti tertentu, Islam menawarkan landasan yang kokoh sebagaimana ideologi lainnya memberikan dasar untuk penyelenggaraan negara.

Secara teoretis, dengan pola hubungan tujuan-sarana, mutlak-relatif, hubungan antara Islam dan negara tidak dapat dimengerti sebagai suatu pola hubungan statis. Artinya, keharusan adanya negara (Islam ) tidak sekuat keharusan adanya agama Islam . Misalnya, kalau dari segi historis dapat ditemukan adanya negara Islam dalam arti sebagaimana dialami oleh Nabi, tidak dapat dimutlakkan bahwa tatanan negara Islam itu diwujudkan dalam masa sekarang ini. (Hal itu akan serupa dengan pencarian demokrasi yang mengimpikan demokrasi asali: demokrasi Athena).

Pola hubungan yang dinamis antara Islam dan negara itu memungkinkan munculnya beberapa penafsiran dan gerakan dalam Islam sendiri. Kelompok yang lebih moderat tentu saja tidak memutlakkan institusi negara Islam sebagaimana ditafsirkan oleh kelompok fundamental. Bahkan, mungkin kebanyakan para tokoh muslim tidak menolak adanya kompromi bahwa negara Islam perlu dimengerti sebagai suatu negara yang dijiwai oleh nilai-nilai Islam. Istilah negara Islam tidak perlu dimengerti sebagai negara yang segala-galanya diatur menurut kaidah Islam, (Santoso, 1997).

Dengan penafsiran yang lebih terbuka itu (kalau tidak dapat dikatakan bahwa Al-Qur'an dan hadits sendiri tidak menyebutkan soal negara Islam ) Islam tidak dapat tidak perlu menemukan ide dasar dalam syari'ah bagi demokrasi. Harus diakui, demokrasi per se bukanlah gagasan Islam, (Aziz, 1993). tetapi toh tidak berarti bahwa Islam tidak compatible dengan gagasan itu. Islam justru harus terbuka pada gagasan demokrasi yang sudah diakui secara universal sebagai satu peradaban yang layak diupayakan demi di dunia yang lebih baik. Kiranya dapat disebutkan di sini apa saja elemen-elemen demokrasi yang perlu ditemukan basisnya dalam Islam .

\section{Demokrasi: Suatu Kesetaraan Politik}

Begitu banyaknya ulasan tentang demokrasi memang dapat menimbulkan kesulitan kalau di antara ulasan itu ada pertentangan: Seorang penulis besar seperti Robert A. Dahl pun bahkan terkeśsan memakai pendekatan tesis-antitesis-sintesis yang cukup menimbulkan pertanyaan besar tentang apa itu sebenarnya demokrasi. Misalnya, gagasannya tentang poliarki menempatkan demokrasi pada tahap terakhir setelah poliarki. Sementara negara-negara yang dianggap sudah mengalami poliarki pun tidak mengalami apa-apa meskipun dikenal sudah sebagai negara demokratis. Di sini pengertian demokrasi seolah-olah dikaburkan juga, (Dahl, 1989). 
Akan tetapi, dari sekian banyak diskusi tentang demokrasi, kiranya ada saja pokok-pokok yang selalu dibahas sebagai elemen penting dalam demokrasi atau elemen penting yang perlu diupayakan oleh demokrasi. Dapat disebutkan di sini elemen demokratis itu sebagai berikut: 1) Ada pengakuan kesetaraan antara seluruh individu. 2) Nilai-nilai yang melekat pada individu mengatasi nilai-nilai yang melekat pada negara.3) Pemerintah merupakan pelayan masyarakat. 4) Ada aturan-aturan hukum. 5) Ada pengakuan atas nalar, eksperimentasi dan pengalaman. 6) Ada pengakuan mayoritas atas hak-hak minoritas. 7) Ada prosedur dan mekanisme demokratis sebagai cara mencapai tujuan bersama, (Taha, 1996).

Dari prinsip-prinsip demokratis ini, kiranya dapat diterima bahwa demokrasi pada akhirnya mengandaikan adanya suatu kesetaraan atau keseimbangan politis. Itu berarti setiap elemen masyarakat memiliki kesempatan dan kemampuan yang relatif seimbang untuk memperjuangkan kepentingan politisnya. Dalam beberapa kajian tentang demokrasi, hal ini dapat dipahami sebagai salah satu unsur demokrasi tetapi mungkin juga justru tidak dianggap sebagai padanan demokrasi, (Dunn, 1992). Akantetapi, akhirnya toh prinsip kesetaraan diterima sebagai basis demokrasi.

Bari paham kesetaraan inilah dapat diturunkan berbagai macam teori demokrasi yang akomodatif bagi gagasan Islam. Artinya, Islam sendiri memiliki basis yang kuat yang mendukung prinsip kesetaraan tersebut. Dengan seiringnya gerak rasionalitas dan inklusivisme Islam, Islam dapat memperkuat basis demokratis tersebut dengan syari'ahnya. Tentu saja, karena Islam memiliki syari'ah yang bersumber pada Al-Qur'an, baiklah di sini sedikit saja disajikan kaidah-kaidah yang dapat dipakai sebagai legitimasi untuk demokrasi sebagaimana digagas oleh Kuntowijoyo, (Wijoyo, 1997).

\section{Kaidah-Kaidah Demokrasi Islamiyah}

Kaidah-kaidah demokrasi di sini kiranya perlu dikembalikan kepada pengertian demokrasi yang mengandaikan prinsip kesetaraan. Prinsip ini dapat diderivasikan pada berbagai ayat diantaranya: Pertama: QS . Al-Hujurat: 13.Pada ayat tersebut menunjukkan teosentrisme dalam Islam yang menyatakan kesatuan sebagai awal eksistensi manusia. Pluralitas kebangsaan yang terjadi pada akhirnya harus dikembalikan kepada prinsip asli dengan kaidah ta'arruf (saling mengenal). Kaidah ini jelas mengandaikan adanya kesamaan, kebebasan, dan juga komunikasi dialogis tanpa dominasi satu kelompok terhadap yang lain. Hal ini jelas sangat penting bagi suatu demokrasi yang efektif. Kedua: pada QS. Asy-Syura: 38 tentang musyawarah. Ketiga: Ali'Imran :159. Ayat ini menurut Bernard Lewis mengungkapkan kewajiban musyawarah dalam Islam, (Lewis, 1994). Prinsip rupanya juga diperkuat oleh sumber sekunder syari'ah, yaitu penghayatan yang dilakukan oleh Nabi sendiri. Kaidah musyarawah ini (syıra) sifatnya inklusif karena 
terbuka juga bagi kelompok non-muslim.

Keempat: QS. Al-Maidah :2 Ayat tersebut menegaskan tentang ta'awun yang diwujutkan dengan tekanan tuntutan untuk kerja sama demi 'kepentingan' Tuhan dan kepentingan manusia sendiri. Di sini prinsip untuk demokrasi dimengerti secara positif sebagai prinsip untuk membangun iklim yang 'bajik' bagi hidup komunitas. Untuk itulah diperlukan kerja sama juga secara positif baik dalam level komunitas kecil maupun dalam level makro. Prinsip ini bermanfaat sebagai proses demokratisasi di setiap tingkat komunitas. Kelima: Kaidah lainnya adalah 'Adl atau adil, yang ditemukan dalam Surah An-Nisa' :58 dilanjutkan juga pada Surah Al-An'am 152. Tentu saja prinsip keadilan ini self-evident penting sebagai elemen demokrasi. Keadilan di sini mencakup keadilan sosial (distributive justice) maupun keadilan ekonomi (prodluctive justice). Cakupan ini diulas lebih lanjut dalam kajian tentang demokrasi sosial dan demokrasi ekonomi oleh Kuntowijoyo.

Keenam: Surah Ar-Ra'd :1। Ayat ini menyatakan bahwa manusia berperan besar dalam menentukan perubahan hidup. Kaidah demokrasi inilah yang terakhir disebutkan oleh Kuntowijoyo dengan istilah Taghyir atau perubahan. Kaidah ini mengingatkan sejarah demokrasi di Atena yang diwarnai oleh tuntutan pergantian anggota Dewan Lima Ratus. Elemen ini tidak dapat dihindari oleh demokrasi yang tidak mengakomodasi kecenderungan status quo, (Dunn, 1992). Demokrasi menuntut suatu perubahan yang memang sejalan dengan perkembangan kesadaran manusia yang selalu ingin mengadakan perbaikan. Ayat tersebut juga mendukung peran manusia dalam berproses untuk berubah, bagaimanapun perubahan itu akan berlangsung. Tentu dari sekian sumber syari'ah itu tidak ada satu pun yang menyebutkan demokrasi, (Aziz, 1993). Dalam batas tertentu memang kaidah ini terkesan menjadi rasionalisasi untuk menyatakan bahwa Islam itu compatible dengan demokrasi. Akan tetapi, hal itu memang perlu dilakukan sebagai upaya kontak dengan arus perkembangan tetapi tetap berbasis. Di sini diperlukan 'dialog' antara Islam sebagai satu kekuatan politik yang besar dan demokrasi sebagai suatu sistem peradaban yang diakui secara universal menjadi cita-cita. Bagaimana sebaiknya Islam 'berdialog' dengan demokrasi?

\section{E. Islam dan Demokrasi: Suatu Nisbah}

Sebelum meninjau nisbah antara Islam dan demokrasi, kiranya perlu disampaikan terlebih dahulu setidak-tidaknya dua catatan penting yang harus diperhatikan. Pertama, Islam dan demokrasi tidak dapat diperbandingkan dalam level yang setingkat. Artinya, Islam sebagai kekuatan politik tidak dapat dilihat dengan mengesampingkan aspek-aspek keagamaan yang meliputi cult, creed, cole, community. Demokrasi tidak memiliki elemen-elemen seperti itu sehingga tidak seimbanglah kalau dibandingkan dengan Islam secara keseluruhan. Dalam hal ini, 
demokrasi hanyalah bagian kecil dari sistem kepercayaan dalam Islam .

Kedua, demokrasi sendiri tidak memiliki arti yang secara tepat disetujui bersama. Kalau demikian, artinya tidak ada basis pijakan yang mutlak wajib dipakai sebagai penentu kajian relasi antara Islam dan demokrasi. Demokrasi tidak dapat menentukan suatu ideal type bagi dirinya sendiri baik dalam definisi maupun dalam implementasinya. Sebagai implikasinya, Islam pun dapat memberi pengertian, memberi isi kepada apa yang disebut demokrasi sesuai dengan kerangka pemahaman yang bernafaskan Islam. Dengan demikian, Islam juga berhadapan dengan instansi lain yang juga memiliki kans untuk memberi penafsiran atas demokrasi.

Kedua catatan ini cukup penting titik tolak untuk melihat sifat relasi antara Islam dan demokrasi. Islam dan demokrasi bukanlah dua entitas yang dapat dipertentangkan begitu saja atau sebaliknya, dianggap 'satu blok'. Di satu sisi, dapat dikatakan demokrasi itu compatible dengan Islam, tetapi, di lain sisi, harus diberi catatan bahwa kecocokan itu ada dalam batas-batas tertentu. Islam tetap memiliki aspek yang dapat memberi kesan ketidaksesuaian demokrasi.

Berkenaan dengan catatan pertama, bahwa Islam dan demokrasi tidak dapat dibandingkan dalam level yang setingkat, kiranya perlu diakui adanya pola hubungan subordinatif dalam paradigma Islam. Pola hubungan subordinatif ini menempatkan Islam sebagai substansi mutlak sedangkan negara menjadi relatif. Di hadapan negara, Islam bersifat mutlak dalam arti bahwa negara dapat menjadi ekspresi nilai-nilai perenial Islam, (Madjid, 1995).

Dari pola hubungan yang demikian juga dapat dimengerti bahwa Islam menjadi tujuan sedangkan negara merupakan sarana saja (betapapun pentingnya sarana itu). Padahal, demokrasi hanyalah satu dari sekian piranti penyelenggaraan negara. Karena itu, dalam batas tertentu dapat dikatakan bahwa Islam pun bersifat mutlak terhadap demokrasi. Kemutlakan Islam kiranya terletak pada kompleksitas dan kelengkapan (setidak-tidaknya menurut klaim agama) sistem gagasannya. Dengan klaim ini Islam memiliki legitimasi untuk memberikan kerangka hidup yang lebih menyeluruh daripada demokrasi. Perbedaan keluasan ini akan menempatkan demokrasi di hadapan hukum dan ajaran Islam . Dengan kata lain, demokrasi dihadapkan pada teologi Islam .

Relasi antara demokrasi dan gagasan teologis Islam (konsisten dengan prinsip tawhid) juga bersifat subordinatif. Artinya, aspek teologis Islam menjadi otoritas tertinggi dan itu berarti demokrasi pun harus menyesuaikan diri dengan "jiwa dari hukum yang diwahyukan, (Ali, 1996). Kalau demikian, memang harus diakui bahwa antara Islam dan demokrasi ada perbedaan esensial. Demokrasi yang muncul sebagai hasil olah pikir manusia membuka peluang besar bagi perubahan nilai oleh masyarakat dan dapat saja perubahan ini justru merongrong nilai abadi dalam Islam (Suaedy, 1994). 
Kiranya di sinilah letak potensi pertentangan antara Islam dan demokrasi, yaitu ketika gagasan-gagasan teologis dalam Islam sendiri berhadapan dengan gagasan demokrasi (yang tentunya tidak dilanclasi perwahyuan transendental). Kasus Mahmud Mohamed Taha (yang dihukum gantung karena menyuarakan hak untuk berpindah agama) dapat menjadi contoh jelas untuk menggambarkan betapa institusi keagamaan, biar bagaimanapun, memiliki sistem kepercayaan yang dapat bertentangan dengan gagasan demokrasi, (Suaedy, 1994).

\section{F. Demokrasi Islamiah}

Berkenaan dengan catatan kedua, bahwa demokrasi tidak memiliki arti secara tepat yang disetujui bersama, dapat dikatakan bahwa demokrasi compatible dengan Islam . Hal ini dapat dimengerti karena adanya kemungkinan bagi Islam untuk memberi pemaknaan terhadap demokrasi. Memberi makna kepada demokrasi berarti menginklusikan demokrasi dalam Islam atau lebih tepatnya memberi warna Islam iah pada demokrasi. Di sini dapat dipahami bahwa syari'ah demokratis menjadi deep driving force yang menentukan pola tingkah laku manusia. Demokrasi tidak dipandang sebagai satu 'budaya' luar (Barat misalnya) tetapi memang secara internal ada dalam Islam sehingga harus dieksternalisasikan menurut syari' ah Islam . Dengan demikian, mungkin akan tampak bahwa demokrasi diberi atribut Islam : demokrasi Islam iah.

Dalam hal ini, demokrasi tidak lagi menjadi kutubyang dihadapiIslam sehingga tidak ada konflik antara keduanya. Kalau ada konflik, hal itu hanya akan memposisikan demokrasi sebagai medium antara Islam dan kekuasaan politik lainnya. Hal ini misalnya ditunjukkan dalam pergumulan Islam dengan kekuatan militer di Indonesia, (Ramage. 1996). Demokrasi menjadi medium pergulatan interpretasi antara aspek-aspek teologis Islam dan aspek-aspek kekuatan politik yanglain. Kedua kekuatan politik ini memang memiliki hak untuk menginterpretasikan demokrasi dan dengan interpretasi itulah keduanya dapat bersitegang.

Dengan demikian, letak konflik bukan antara Islam dan demokrasi, melainkan antara Islam dan kekuatan politik lain. Islam dan demokrasi, biara bagaimanapun, dalam batas catatan kedua tadi, bertalian kuat sehingga dapat dikatakan bahwa Islam compatible dengan demokrasi dan sebaliknya. Syari' ah demokratis memberi legitimasi pada demokrasi untuk disebut sebagai sistem gagasan yang Islam iah. Selain itu, secara historis Islam sendiri memiliki tradisi yang menunjukkan ciri-ciri demokrasi. Keadaan bahwa kepemimpinan ditetapkan atas dasar achievement, proses pemilihan terbuka, hak dan kewajiban rakyat yang sama, pengakuan hak pada golongan agama lain, secara historis menunjukkan keunggulan Islam sebagai kekuatan politik yang luarbiașa pada masanya, (Madjid, 1995). Keadaan ini menjadi salah satu gambaran bagaimana Islam mewujudkan demokrasi dengan ciri-ciri 
demokratis yang dimilikinya. Aspek historis yang menjadi tradisi pada masa awal perkembangan Islam itu menunjukkan peluang adanya Islam demokratis.

\section{G. Penutup}

Agama Islam memuat ajaran-ajaran teologis dogmatis dan scientific applicative. Ajaran pertama tercermin dalam ruang lingkup dasar-dasar keimanan kepada dzat yang adi kodrati yaitu Allah SWT (hablum minallah/ hubungan baik kepada allah). Sedangkan ajaran kedua lebih menitik beratkan pada hubungan manusia dengan masyarakat sosialnya (hablumminannas/ hubungan baik kepada manusia).

Dalam terminology kedua itulah makna demokrasi mendapat perhatian besar dalam Islam sebagai wijut konsep pembinaan keharmonisan kehidupan manusia. Maka demokrasi mengambil berntuknya dalam aspek-aspek: kesetaraan, musyawarah, kerja sama, adil, dan kebebasan menentukan pilihan dan kehendak yang bertanggungjawab.

\section{Daftar Kepustakaan}

Agus Edi Santoso (ed.) 1997. Tidak Ada Negara Islam (Surat-Surar Politik Nurcholish Madjid-Mohamad Roem.). Jakarta: Penerbit Djambatan.

Ahmad Suaedy. et al. (ed.). 1994. Spiritualitas Baru: Agama dan Aspirasi Rakyat. Yogyakarta: Penerbit Institut Dian/Interfidei.

Dahl, Robert A. 1989. Democracy and Its Critics. New Haven \& London: Yale University Press.

Dunn, John (ed.). 1992. Democracy' The Unfinished Journey'. New York: Oxford University Press.

Kuntowijoyo. 1997. Identitas Politik Umat Islam . Bandung: Penerbit Mizan.

Lewis, Bernard. 1994. Bahasa Politik Islam . Jakarta: PT Gramedia Pustaka Utama. Terjemahan oleh Ihsan Ali-Fauzi.

M. Imam Aziz. er al. (ed.). 1993. Agama, Demokrasi \& Keadilan. Jakarta: PT Gramedia Pustaka Utama.

Mahmoud Mohamed Taha. 1996. Syari'ah Demokratik. Surabaya: ELSAD. Terjemahan oleh Nur Rachman.

Maulana Muhammad Ali. 1996. Islam ologi (Dinul Islam ). Jakarta: Darul Kutubil Islam iyah. Terjemahan oleh R. Kaelan dan H. M. Bachrun.

Nurcholish Madjid. 1995. Islam Agama Kemanusiaan. Jakarta: Yayasan Wakaf Paramadina.

Ramage, Douglas E. 1996. Politics in Indonesia: Democracy, Islam and Ideology' of Tolerance. New York \& London: Routledge.

Watt, W. Montgomery. 1968. Islam ic Political Thought. Edinburgh: Edinburgh University Press. 